\title{
Aspects of Victorian Serial Publication in Neo- Victorian Fiction: The Glass Books of the Dream Eaters and The League of Extraordinary Gentlemen
}

\author{
Sabina Fąli
}

A large number of Victorian novels that readers today encounter as one-volume editions had originally appeared in instalments, either in periodicals or part issues. Additionally, before serial novels were reprinted in three-, two-, or one-volume editions, the texts were often revised and adapted to the new form. Although serialization was not invented by the Victorians, it had an especially prominent place in $19^{\text {th }}$-century print culture in which, Mark Turner observes, "serial reading became pervasive and, arguably, the most significant literary form for much of the century" $(2005,115)$. Some characteristic features of the Victorian serial are today evoked in postmodern neo-Victorian and steampunk texts.

Serialization was an important aspect of $19^{\text {th }}$-century publishing that shaped both the Victorian readers' habits and experiences of texts and the texts themselves. Victorian authors had to mold their stories to the serial form, and the prerogative of motivating readers to buy the next number affected the way they conceived their plots. Charles Reade's formula of “make 'em laugh, make 'em cry, 
make 'em wait" encapsulates the strategy of emotional involvement, suspense, and deferral. ${ }^{1}$ The context of serial novels was thus markedly different from their later one-volume reincarnations.

The start of Charles Dickens's The Posthumous Papers of the Pickwick Club in 1836 is usually taken as the moment when serial publication really took off. The Pickwick Papers were published in monthly parts and ran until 1837. They were sold in "distinctive duck-green wrappers" (Law 2000, 18) and framed by pages of advertising, which made up about one third of each number (Williams 2010, 319). The advertising that appeared in these pages mainly consisted of microscopic print and had been written by salesmen themselves rather than specialized agencies (Wicke 1988, 36).

Much more so than in their modern one-volume editions, the fictional world of serialized novels was disrupted by the forced period of waiting for the next instalment. Through the extended temporality of serial reading, the reader's life was entwined with the fictional world in the text. As Linda K. Hughes and Michael Lund have argued, reading fiction in instalments re-enacts Victorian conceptions of history, progress, and personal development as requiring patience and steady work. As such, the serial was embedded in dominant Victorian notions of gradual and long-term change on the level of both individual biography and history (Hughes and Lund 1991, 4-6). In everyday life, reading a narrative stretched over several months with interruptions between instalments means that the intervals can be filled with speculations on the development of the story and the fate of the characters. These discussions with neighbours and family enhance the readers' emotional connection with the protagonists (10). This shared anticipation not only has a private or local but also a national dimension. Unlike the solitary reading of a one-volume edition, serial reading on this scale creates a "community of readers" who share their speculations and collectively engage in the same rituals such as the anticipation of "magazine day" (10).

Victorian writers also self-referentially commented on the genre's success in their own (serialized) texts and depicted the spellbound reader of serial novels. Elizabeth Gaskell's Cranford (which ran in Dickens's Household Words in 1851) takes up the excitement generated by serial fiction. Captain Brown, a new addition to the mostly female circle of Cranfordians is reading the latest instalment of the Pickwick Papers just before he is run over by a train: as a witness to the tragic death reports, Captain Brown was "[a]-reading some new book as he was deep in" (Gaskell $1851 / 2009,24)$. In this episode, Gaskell assembles two striking features of Victo-

1 This quotation has been variously attributed to Wilkie Collins, Charles Dickens, and Charles Reade. In Dead Secrets, for instance, Tamar Heller writes that “'[m]ake 'em cry, make 'em laugh, make 'em wait' was one of his [Collins's] mottoes" $(1992,7)$. Dahlquist's commentary in The Guardian uses the phrase in its title attributing it to Collins, and five days later adds a correction: "The headline quotation 'Make 'em cry, make 'em laugh, make 'em wait' in this article, attributed in the text to Wilkie Collins, is usually ascribed to Charles Reade as 'Make em laugh; make em cry; make em wait.' (See Webster's Online Dictionary under Em)" (Dahlquist 2007b). 
rian modernity: serial publication engendering the avid and immersed reader of serial fiction, and the train as the epitome of progress and changing perceptions of time. Captain Brown has not only longingly waited for the next instalment of the story, he also had to defend his passion for serial literature against allegations of frivolity against Cranford's arbiter of 'high literature,' Deborah Jenkyns, who is a follower of Johnson. The character of Captain Brown in this scene stands for the serial reader who struggles with the blurred line between fictional and real world, which was an enduring concern in reviews of serial literature. In 1845, an anonymous contributor to The North British Review complains that

the form of publication of Mr. Dickens' works must be attended with bad consequences. [...] The monthly number comes in so winningly, with methodical punctuality, and with so moderate an amount at a time, that novelreading becomes a sort of occupation, and not to have seen the last number of Martin Chuzzlewit is about as irregular as not to have balanced your books. (Anon. 85)

The reviewer also notes the anxiety evident in Captain Brown's predicament, the serial reader's dangerous immersion in the text:

It throws us into a state of unreal excitement, a trance, a dream, which we should be allowed to dream out, and then sent back to the atmosphere of reality again, cured by our brief surfeit of the desire to indulge again soon in the same delirium of feverish interest. But now our dreams are mingled with our daily business. (85)

The readers of Gaskell's serial novel experienced the same mingling of "daily business" and "dreams" that preceded Captain Brown's accident. The success of the serial novel in the Victorian period was accompanied by its denigration as a low and commercial form. Serial publication especially highlighted the interaction of writers and the marketplace, and writing in numbers was perceived as reducing art to a 'mechanical' routine. The schedule of producing text for regular instalments seems to be at odds with romantic notions of the inspired genius (Turner 2005, 118-119). Serial fiction, and especially sensation novels which dominated the market in the middle of the century, were suspect to critics because of both their mass appeal and close association with writing as a trade. The anonymous contributor to the 1845 article on Dickens also complains about another effect of the serial novel as part of the market place. Readers' wishes, she or he argues, can directly influence the author: "it is scarcely necessary to add, how very injurious to the novel, as a work of art, this mode of publication must be, and the opportunity it gives to the author to know the sentiments of the public, and to them to interfere with the conduct of the tale" (Anon. 86). The article decries the direct influence of the (mass) reader's taste on the work of art, which compromises its place in high culture. 
Through its paratexts, the format of the serial novel not only addressed readers as readers but also as consumers of services and commodities: part-issued novels, for example, were often accompanied by supplements that carried adverts. Economic concerns were thus not only seen as marring the production of serial novels but also as impinging on the context in which fiction appeared in periodicals which, in turn, contaminated the novel. A review article on sensation novels complained that "[a] periodical, from its very nature, must contain many articles of an ephemeral interest, and of the character of goods made to order," soliciting "tales of the marketable stamp" (Mansel 1863, 484). Fiction increasingly viewed as a commodity is thus placed alongside advertisements for other, equally ephemeral, products, and both elicit "only a transitory interest" (484) in readers and consumers. Advertising began to boom between 1850 and 1880 due to new illustration techniques, professionalization of publishers and press, and the rise of disposable income among possible consumers, which made advertising worthwhile in the first place. Apart from its appearance in print media, advertising also expanded in the urban space through bill posting (starting in the mid-century), large shop windows (from about the 1830s), and illuminated advertising (in the 1890s) (Eichhammer 2013, 108). Charles Dickens's Pickwick Papers, which blazed the trail for Victorian serial fiction, ran from March 1836 to November 1837. In each number, "The Pickwick Advertiser" precedes the adventures of the Pickwick club and about ten pages of advertising follow after it (Williams 2010, 319). Advertising and illustrations framed fictional narratives both in the format of monthly parts and in magazines. In the latter, fictional texts also appeared alongside journalism and news. The result of reading novels in the context of periodicals or as part-issues together with 'advertisers' and wrappers is that the fictional text is not the but just one text among many. Laurel Brake, for example, calls this "the heteroglossia of these hybrid texts" (2001, 222).

Advertising and fiction often complemented each other, either intentionally or coincidentally. The advertisers that accompanied the individual numbers of Bleak House and Our Mutual Friend, for example, use the same gothic rhetoric as the novels themselves, which leads to a continuum rather than breaks between the genres (Thornton 2004, 61-64). Laurel Brake points out another such dialogue between fiction and advert in Daniel Deronda when the instalment ending with the sentence: "She was found in this, crushed on the floor. Such grief seemed natural in a poor lady whose husband had been drowned in her presence' (Eliot 1871/72, Book VII, r62) is juxtaposed with an advert on the back wrapper recto for the Scottish Widow's Fund" (Brake 2001, 221-222). A second type of advertising referred to other novels or poems: for example, periodicals usually carried adverts for serial novels that would start in the next number while the last instalments of the previous novel were still running, which would also create interesting overlaps and suggest continuities that might not have been intended as such. 
Adverts, news, and journalistic pieces constitute paratexts that materialize the intertwining of fiction and real world that especially troubled Victorian critics of serial novels. Magazines and wrappers that carry advertising, classified ads, and journalism create the space in which such mingling takes place. The term 'paratext' has been coined by Gérard Genette to denote "verbal or other productions" that surround the literary text and allow for its publication and 'presentation' to the reader $(1997,1)$. To emphasize the function of the paratext as a permeable boundary between text and off-text, Genette uses spatial metaphors from architecture describing this space as the "threshold" or "vestibule' that offers the world at large the possibility of either stepping inside or turning back" (2). He further differentiates paratexts according to their location. The 'peritext' can be found "within the same volume" (4) and is thus defined by its spatial proximity to the text proper. In contrast, the 'epitext' consists of the more "distanced elements" that are not part of the volume and may include not only diaries, letters, and reviews but also other media (5). The Victorian serial novel can be described as existing in a rich paratextual frame both inside the periodical or part issue and through communal reading practices in the real world.

\section{Victorian Reading in the $21^{\text {st }}$ Century}

A new appreciation of the importance of original Victorian publishing formats for novels and other texts has led to attempts of recreating the Victorian experience of reading. However, investigating such planned or accidental matches between fiction and periodical paratext is often hampered by the design of magazines which made sure that the front and back pages carrying ads could easily be removed before being bound in one volume (Lauterbach 1967, 431). But several projects have been dedicated to recuperating - often in an academic context - the temporal aspect of serial reading, such as the "No Name Reading Project" on Dickens Journals Online (2006), which has, as yet, completed two novels accompanied by discussions on blogs; Stanford University's Discovering Dickens: A Community Reading Project (2005); and Christopher Hapka's Mousehold Words (n.d.). Hapka writes that through his web page the reader

can experience these great works just as their first readers did. MOUSEHOLD WORDS emails you one serial part at a time, just as Dickens' or Dumas' readers would have read them, on a schedule you choose. Our digital serial editions feature the original serial divisions and are professionally edited and formatted for reading on your tablet, mobile device or computer.

To "experience these great works just as their first readers did" implies a desire to understand a different way of reading the often canonized Victorian text helped by "tablet, mobile device or computer." In a short piece in which he reflects on the 
challenge of writing and reading in instalments, Dahlquist compares the Victorian communal reading of numbers in the family circle with the discussion of new instalments in online communities (2007b). In 2012, The Observer reported on Amazon's plans to sell e-books in instalments. Although serial fiction by no means ended with the period, the article evokes serial reading as typically Victorian, and its evocation of Victorian seriality and Amazon's reference to the social aspect of serial reading are worth quoting:

In 1841, a British cargo ship caused a riot as it docked in New York harbour. It was carrying the next instalment of Charles Dickens' latest blockbuster The Old Curiosity Shop, and the mob was anxious to learn the fate of Little Nell. Serialised fiction has fallen out of fashion since its 19thcentury heyday, but that could be about to change with Amazon's Kindle serials range, just launched in America. Using the internet to revive the form that gave us Middlemarch and Anna Karenina is not a new idea. Stephen King tried it 12 years ago with The Plant and, in 2008, the Telegraph website published Alexander McCall Smith's serial novel Corduroy Mansions. Where Amazon's venture differs is its convenience: users pay for the story upfront, with new chapters delivered to the Kindle as soon as they are published. Amazon is also playing up the social side. "Join the discussion," implores Jeff Bezos, and you can see how episodic storytelling, with its cliffhangers and multi-stranded plots, might lend itself to virtual watercooler chat. [...] How exciting would it be if an author were to use this neo-Victorian format to breathe life into the state-of-the-nation novel? (Baddeley 2012)

This new interest in reading Victorian novels in a form that approaches their original shape as well as the reference to serial reading as 'Victorian' dovetail with creative texts that go back to the Victorian period to engage with the Victorian past through texts. Mark Llewellyn describes neo-Victorian texts as "in the main, processes of writing that act out the results of reading the Victorians and their literary productions" $(2008,168)$. Neo-Victorian fiction as a genre that thematizes the act of reading and the importance of textuality to access the past sometimes references the aspect of Victorian seriality by addressing the $21^{\text {st-century reader as a Victorian }}$ consumer of serial novels.

Thus The Guardian serialized the first chapter of Michel Faber's The Crimson Petal and the White before the book was published. Faber wrote an introduction to the first instalment in which he points out serial reading as an attempt to recapture a Victorian experience in the present:

She [the first reader who read the instalments before publication] told me she understood what Victorian readers must have felt like, waiting on the docks for the arrival of the latest Dickens serial. Now the Guardian is offering you the same experience. My story will be disassembled into bytes, 
injected into a website, and, when you download it, the year 1875 will reconstitute itself before your very eyes (Victorian hype). [...] [Y] ou be the judge. I have done my best to offer you a world that feels lived in and characters for whom you can care. Follow the signs to the 19th century; read on. (Faber 2002)

As in the case of Mousehold Words, serial reading becomes possible by way of new media, and the internet allows for shared anticipation and speculation among readers. However, in this detour, Faber ironically promises the reader "the same experience" as the Victorian reader of serial fiction. In the same vein, when readers complained about the inconclusive ending of Faber's The Crimson Petal and the White, he answered in the preface to the collection The Apple: Crimson Petal Stories: "[I]sn't it fun, at the end of a book, to be challenged to do what the Victorians were obliged to do between installments of serialized novels: construct what happens next in our imaginations?” (Faber 2011, xvi). In his response, Michel Faber alludes to the re-enactment of Victorian reading for $21^{\text {st-century readers. This is }}$ arguably possible by tentatively inhabiting the Victorian reader's set of expectations about the following instalments, especially the anticipation during the enforced pause between parts of serialized fiction. In Faber's description, this process relies as much on the imagination of the reader as on the novel's tentative open ending. It directly involves the reader in the perpetuation of the plot and engenders immersion on more than one level. In these two instances, Victorian seriality seems to be part of the desire to access an authentic "world that feels lived in" (Faber 2002), including instant gratification and the author's ironic reminder that this would actually have involved waiting for and imagining the next instalment. Both the serial reading projects of Victorian classics and neo-Victorian forays into seriality suggest that serial reading somehow reduces the distance between the $21^{\text {st }}$ century reader and the Victorian period.

In the following, I would like to look at how two neo-Victorian and steampunk texts reference serial publication and periodical paratexts to suggest a Victorian context for their consumption. I will concentrate on the 'heteroglossia' of serial fiction and the danger posed by immersion in serial fiction.

\section{The Glass Books of the Dream Eaters: Immersed Readers and Serialization}

In Gordon Dahlquist's steampunk fantasy The Glass Books of the Dream Eaters, ${ }^{2}$ serialization is both a marketing strategy and ties in with the diegetic concern about

2 The Glass Books of the Dream Eaters is Gordon Dahlquist's first novel, published in 2006, followed by The Dark. Volume in 2008 and The Chemickal Marriage in 2012. The novels constitute the Glass Books trilogy. 
reading material and readers. Viking published the first edition of the Glass Books in weekly part-issues between September 2006 and January 2007, each part ending in a cliffhanger. Interestingly, the decision to publish the novel in parts was taken by Viking to match the format to the novel's Victorian setting (Dahlquist 2007b). Readers could subscribe for the issues on the publisher's website, and in The Guardian's column "The Bookseller," Joel Rickett commented that Viking anachronously "resurrect[ed] the faded art of the fiction serial" (2006), a phrase that echoes both Michel Faber and Mousehold Words. In a commentary titled "Make 'em cry, make 'em laugh, make 'em wait," Dahlquist reflects on the implications of writing and reading in parts, which brings readers "in touch with another sort of reading altogether." The difference lies in "an appreciation for partial knowledge as a natural state of mind [...] [T] he experience of reading in pieces acclimatizes one to a different sort of satisfaction, more rooted in the present, where events are appreciated without the conventional endings yet to come" (Dahlquist 2007b).

The novel is set in an unnamed place and unidentified period strongly resembling Victorian Britain. The glass books of the title are a fantastic medium to store memories and experiences and make them available for others to read or re-experience. Dr. Svenson, one of the protagonists, describes reading glass books as follows:

It was like entering someone else's dream. After a moment the blue cast of the glass vanished as if he had pierced a veil ... he was staring into a room - a dark comfortable room with a great red sofa and hanging chandeliers and luxurious carpets - and then [...] the image moved, as if he was walking, or standing and turning his gaze about the salon - and he saw people, people who were looking right at him. He could hear nothing save the sound of his own breath, but his mind had otherwise fully entered the space of these images - moving images - like photographs, but not like them also, at once more vivid and less sharp, more fully dimensional and incomprehensibly infused with sensation [...]. (Dahlquist 2007a, 147-148; emphasis in the original)

Another character in the novel compares reading blue glass to swimming, "so immersive were the sensations, so tactile the images" (204). Glass-book reading conveys an extraordinary sense of immediacy and involvement, which echoes the sense of 'immersion' that Janet H. Murray describes in Hamlet on the Holodeck as "the sensation of being surrounded by a completely other reality, as different as water is from air, that takes over all our attention, our whole perceptual apparatus" $(1997,98)$. The glass books open two avenues for interpretation and seem to reference two media scares: contemporary games and new media, and Victorian 'scandalous' literature from sensation fiction to pornography.

The Glass Books of the Dream Eaters projects the image of the rapt readers, oblivious to their surroundings, which is familiar from Victorian discourses on harmful reading and its somatic effects on the body and especially registers in the critiques 
of serial fiction. The glass books are part of such a negative discourse of addiction and are even labelled "another kind of opium" (Dahlquist 2007a, 222). Immersed readers are mesmerized by the scenes played in front of their eyes, and they are unable to put down the book or crave always to read more: "[T] here must be many, many of them - let me see this one again - I want to see them all" (420; emphasis in the original). Tasting glass books once leads to an unhealthy appetite for more, which makes the medium an effective tool of control exploited by a secret society.

In the character of Miss Temple, the novel's main protagonist, the interplay of gender, immersed reading, and its effect on the body is spelled out. She is an especially voracious reader of glass books as she inadvertently consumes two whole books that hold the memories of her two most dangerous enemies. She survives both readings (which could have been lethal) but the memories of the seductive and cruel Contessa Rosamonde di Lacquer-Sforza and the mad and dying Conte Orkancz, harvested just before his death, become enmeshed with her own and threaten her identity: " $[\mathrm{H}]$ er awareness was subsumed within the immediacies of whichever sensation entrapped her. It felt to Miss Temple that she had plunged into the experience of several lifetimes piled up in delirious succession [...] they threatened the very idea of Celeste Temple as any stable entity" (430). These acquired or grafted memories are corrupting both because of their erotic and lurid character and because they cause bodily symptoms that resemble consumption. This trope of the (immersed) female reader as immediately affected by inappropriate and stirring reading suggests sensation fiction and especially Victorian representations of female reading bodies as a historical layer. Victorian critics condemning the spread of sensational literature consumed by all classes, and especially women, framed this reading in terms of affects and effects of the body. In 1863, H.L. Mansel famously decried sensation fiction as "[p]reaching to the nerves instead of the judgment" (481), by-passing reflection, and working immediately on the body. In the same vein as reading was imagined as bodily corruption, it was also considered addictive: readers consume too much and crave even more (as in the proliferation of serial publications and the institution of magazine day), while the content corrupts the imagination of innocent women. Indeed, as far as Miss Temple is concerned, the book "swallows" her (Dahlquist 2007a, 430), and the memories are so powerful that "Miss Temple wondered if she had become the most thoroughly debauched virgin in all history" (433). The dangers of glass books as immersive media thus evoke the Victorian discourse about sensational, dangerous, and pornographic reading matter for women, yet add a twist because Miss Temple is an empowered consumer of books: she uses the 'dangerous' memories that the glass books have implanted in her mind against her enemies and significantly contributes to their downfall through her involuntarily acquired knowledge about their plans and machinations. Therefore, gaining illicit knowledge that would be withheld from women is a step in Miss Temple's emancipation. The novel thus turns Miss Temple into a consumer who can master the dangerous medium of blue 
glass and simultaneously escapes the restricted role of the Victorian female reader. The text may hence be read as constructing the experience of glass book reading as historically multi-layered: as gesturing towards the $19^{\text {th }}$ century, when novels and women's reading held the potential for scandal, and towards the present, as implied in the technology's functioning as a portal to a virtual world.

The story of precarious immersive reading is accompanied by a paratext that evokes Victorian serial novels and their advertisers. At the back of the 2007 onevolume edition, six pages are dedicated to lost-and-found ads and other advertising that draw a line from the paratext to the story. After a pastiche Penguin ad, the reader encounters, for instance, the lost-and-found section in which Miss Temple's notebook and mask, which she lost at the beginning of the story, reappear. The aesthetics of the adverts pastiche Victorian patterns of small and copious text and a wild mixture of fonts to attract attention. Rhetorically, exhaustive lists and hyperbolic testimonials parody Victorian print ads. An advert for "Pingmann's Wax," for example, draws on the Victorian trope of selling commodities through reference to the Empire: “Pingmann's kept my whiskers at attention throughout a forced march from Delhi to Calcutta that saw half my men on their backs!' Colonel James Blunt, of the 4th Dragoon Guards" (Dahlquist 2007a, n.p.). Other adverts refer directly to events in the novel so that the supplement posits the novel as existing within the fictional world it contains. In the last ad, the secret society that controls glass-book production solicits investors for its mining operation to extract the raw material for blue glass. Through the adverts, the Glass Books draws attention to the fictionality of the depicted world. At the same time, the initial serialization and ads evoking periodicity tie in with the text's concern with dangerous and corrupting reading matter by evoking Victorian and contemporary discourses of dangerous media.

\section{The League of Extraordinary Gentlemen (I+II): Serialization and Advertising the Empire}

Alan Moore and Kevin O’Neill's graphic novel The League of Extraordinary Gentlemen

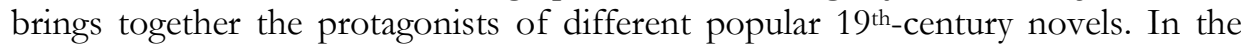
first volume, the league is called on to retrieve a sample of "cavorite," an anti-gravity substance. In the second volume, the heroes of the league deal with a Martian invasion of Britain. The characters have been drawn from popular $19^{\text {th }}$ and turnof-the-century texts. The members of the league are Mina Harker, Allan Quatermain, Dr. Jekyll, Captain Nemo, and Hawley Griffin. Of these main characters, the last two have been borrowed from stories that originally appeared in periodicals: Twenty Thousand Miles under the Sea ran in the Magasin d'éducation et de récréation from 1869-1870 and Wells's Invisible Man first appeared in Pearson's Weekly in 1897. The first six issues of The League of Extraordinary Gentlemen were published between March 1999 and September 2000, and the second series ran from September 2002 
to November 2003. In volume one, among the reproductions of the covers of the different independent issues, one page shows the portraits of the league's members on collectible cigarette cards of the brand "blue dwarf cigarettes." Their characters, "the Empire's finest" (caption with text by S. Smiles, Moore and O'Neill 2000, end of ch. 2), are commodified as promotional material and are themselves turned into parts of a collectible series. The world of The League of Extraordinary Gentlemen is replete with literary and cultural references and creates a web of fictional texts and Victorian allusions that is impossible to disentangle. Moore and O'Neill invite the reader to spot and unravel the often obscure references, which turns reading into an intertextual and metafictional game (Domsch 2012, 100; Sulmicki 2011). In the following, I will point out only some aspects that tie the narrative back to Victorian seriality.

Hughes and Lund (1991) identified the temporality of serial reading as an important feature in its reception. In The League of Extraordinary Gentlemen, at the end of each collected issue, an editorial voice (probably the fictional editor S. Smiles) coaxes the reader to buy the next issue: "Do not fail to reserve the next edition of our illustrated chapbook and thus learn the outcome of this rousing and invigorating narrative!” (Moore and O’Neill 2000, end of ch. 3); “[i]n next month's harrowing conclusion to our splendid serial narrative we shall transcend the very boundaries of human spectacle" (end of ch. 5); and "[b]uy our next issue, lads, and let it be your proof of loyal citizenship! God save the Home Secretary!" (2003, end of ch. 3). The hyperbolic insertions interpellate a young male Victorian reader caught in the loop of serial reading, alternating between rapt reading and the agonizing wait for the next issue. The status of this editorial comment, which belongs to the rhythm of serial reading, changes when the reader encounters it in the onevolume editions. Rather than having to wait for the next issue, the reader can turn the page and read on. As a remnant of the serial publication of the League series, S. Smiles's exhortations can be read as a reminder of other publishing formats. Lara Rutherford considers the role of the interpellated reader in Moore and O'Neill's narrative, and she argues that "these features borrow heavily from a staple of Victorian children's literature: the cheap weekly serial printed on a mass scale for working and middle-class juveniles" (2012, 127-128). The conflict concerning appropriate reading, which centres on mass literature and those especially susceptible to its influence, woman and child readers, also appears in the editor's advice that "mothers of sensitive or neurasthenic children may wish to examine the contents before passing it on to their little one" (Moore and O’Neill 2000, end of ch. 5)

1 According to Jess Nevins's notes on The League of Extraordinary Gentlemen hardcover edition, "'Sapathwa' is better known as the penny dreadful villain The Blue Dwarf. The Dwarf was a penny dreadful character who first appeared in 1861 and was the companion-in-arms (and crime) of Dick Turpin, the archetypal heroic bandit and highwayman of the penny dreadfuls. The Dwarf was a nobleman in disguise whose portrayal varied from being an evil influence over Dick to a faithful friend to him" (2000). 
(Rutherford 2012,128). As in the Glass Books, references to Victorian seriality and the paratexts suggesting periodicals evoke the Victorian discourse on the distinction between appropriate, edifying, and corrupting reading material, which centred on serial fiction.

Moore and O'Neill's references to Victorian seriality and its 'heteroglossia' also include advertising both in the paratext and the story. The first issue of volume one starts with a close-up of Campion Bond lighting a cigarette. In the fifth panel, the details of the match box show that this is a branded commodity as the packaging reads "John Bull - Simply no match" by "Bryant \& May London" (Moore and O'Neill 2000). The brand logo and text are clearly visible in this close-up panel, while only Campion Bond's fingertip appears at its edges, resembling an advert in which the product is offered to the viewer or reader as the sole focus of the scene. Bryant and May match boxes were famous for adapting their designs to different customers with different images and text for the colonies and elaborate advertising in Britain (Briggs 1990, 200). These close-up panels are followed by a wide-angle shot of the unfinished Channel Causeway, a huge bridge spanning the channel, which was then under construction. The one-page panel of the bridge introduces many themes that underlie the series. Sebastian Domsch reads this panel as establishing The League of Extraordinary Gentlemen's steampunk perspective on Victorian utopian visions $(2012,110-111)$. The huge construction is decorated with statues of Britannia and a lion and inscribed with the words "INDUSTRY" and "ALBION REACH" (Moore and O'Neill 2000). The page also carries the title of the first issue, "Empire Dreams," in the bottom left corner, which integrates seamlessly with the text inscribed on the bridge. This affirmative view of Empire and progress ironically contrasts with a small plaque announcing a "revised completion date of February 1902, owing to Mechanical difficulties." The gigantic structure that celebrates and affirms the worth of industry also contrasts with the match box in the close-up on the preceding page, the literal object of industry. Bryant and May's Fairfield works in Bow are famous for the 1888 match workers' strike, largely led by Annie Besant, in which unionized workers demanded better pay and working conditions. The workers' organization and perseverance as well as their backing by women from the middle classes made the match girls a powerful and encouraging example for later strikes (Price Paul 1988, 483; Briggs 1990, 199-205). In terms of publicity, the strike did more to publicize the brand "than any of the many advertisements placed by Bryant and May during the 1870s and early 1880s" (Briggs 202). Much like the ironic plaque on the half-finished bridge, the inclusion of the Bryant and May's match box might be another, more oblique reminder that the stability of industry and Empire was under revision.

In both volumes, two other iconic Victorian brands reappear throughout the story: Pears' Soap and Fry's Cocoa, often present together on one page or even in one panel. The words are sometimes painted in large letters on the walls of buildings but also half obscured by figures or structures in the foreground. In issue three, for instance, the word "FRY'S" is visible, chiselled on the side of a bridge, 
and an omnibus passing over the bridge has the word "PEARS" (Moore and O'Neill 2000) painted on its side (which also appears on the wall of a house in the background of the two preceding panels). The two logos appear most prominently when being pasted on the walls of Wildwood train station in the first panel of the last issue in volume II, and in their combination work like a shorthand for an environment permeated by advertising. Pears' Soap was indeed one of the most proliferous marketers of its product with its budget for advertising rising enormously in 1865 under the founder's grandson, who is said to have quipped that "any fool can make soap, it takes a clever man to sell it" (Briggs 1990, 326). In an article analyzing soap as a Victorian commodity, Sabine Schülting describes how Pears' "Bubbles" advert famously appropriated Millais's painting for its campaign $(2001,142)$. In fact, Pears' ads were virtually omnipresent at the turn of the century (137) and especially exploited racist images of the Empire to link consumption with nationalism. An 1899 magazine advert, for instance, contains the caption: "Pears' Soap is a potent factor in brightening the dark corners of the earth as civilisation advances" (qtd. in Schülting 2001, 138). On the important place of soap in Victorian commodity culture, Schülting remarks that "[i]t is thus not an exaggeration to suggest that in the Victorian Age soap had been converted into the epitome of a hedonistic consumer culture" (147). Fry's cocoa beans were grown as an export crop in West Africa, and the company also produced iconic advertising that harnessed images of Empire, much like Pears' (Ramamurthy 2003, 88-90). Yet while Pears' marketing capitalized on the export of civilization to the colonies, cocoa promised the consumption of a colonial commodity at home. In the graphic novels, the pairing of the two products presents the city as a hub of imperial trade and consumption. The still recognizable Victorian brands might also contribute to a sense of the neoVictorian world as "a world that feels lived in" (Faber 2002) and that mirrors the "contemporary late capitalist and globalised market" on which "the nineteenth century in twentieth- and twenty-first-century culture" is "packaged to appeal to a wide consumer base" (Boehm-Schnitker and Gruss 2011, 1).

But The League of Extraordinary Gentlemen also contains more traditional adverts that might be expected in the paratext of a serial novel. In the first volume, a onepage ad announces the start of a new "serial story" which is "just commencing in "THE RIVAL" (Moore and O'Neill 2000). The second volume features one page of real and pastiche Victorian adverts for corsets, erotic photographs, "Peterson's bicycle skirt holders," a cure for "the effects of self-abuse," and an ad for a "hand's free Bawdy Browsing Mechanism" which will "surely be required when you peruse the scandalous displays in THE LEAGUE OF EXTRAORDINARY GENTLEMEN" (Moore and O'Neill 2003). The ad with the legend "ANTI-STIFF. To strengthen the Muscles" not only appears on this separate page but can also be seen in a train carriage in issue three of the same volume. As in the Glass Books, this detail bridges text and paratext. In volume one of the League, two sepia drawings blur the line further. In the first, a sandwich man stands at a street corner with the board advertising the first number of "Alan and the Sundered Veil" (Moore and 
O'Neill 2000), a story which starts on the next page. The drawing that follows the short story shows a bill poster in front of a wall plastered with posters, one of them advertising the League "Cover Gallery" on the reverse page with an arrow pointing to the edge of the page. This connects navigating the city streets with turning the pages of the book. Both spaces are connected by the ads that appear on the walls of the buildings in the panels and in the paratextual drawings.

Both Dahlquist's novel and Moore and O'Neill's graphic narrative adopt aspects and discourses of Victorian serial fiction and rework them in their neo-Victorian worlds. The scare about inappropriate reading and the dangers of immersion as well as periodical literature's 'heteroglossia' re-appear in neo-Victorian transformations. The notion of serials' 'heteroglossia' especially ties in with steampunk's hybridity, which is one of the genre's constitutive features (Bowser and Croxall 2010, 26) "as a fiction of many ingredients" (Hantke 1999, 248).

\section{Works Cited}

\section{Primary Sources}

Dahlquist, Gordon. The Glass Books of the Dream Eaters. London: Penguin, 2007a.

Faber, Michel. Foreword. The Apple: Crimson Petal Stories. Edinburgh: Canongate Books, 2011. ix-xix.

Gaskell, Elizabeth. Cranford. 1851. London: Penguin, 2009.

[Mansel, H.L.]. "Sensation Novels." Quarterly Review 113.226 (1863): 482-514.

Moore, Allan, and Kevin O'Neill. The League of Extraordinary Gentlemen. Vol. I. New York: Vertigo, 2000. [N.pag.].

---. The League of Extraordinary Gentlemen. Vol. II. New York: Vertigo, 2003. [N.pag.].

\section{Secondary Sources}

Anon. "[Rev.] Writings of Charles Dickens." The North British Review 3 (1845): 65-87.

Baddeley, Anna. "Will Amazon's Victorian venture be a serial thriller? Serialised novels, huge in the 19th century, are about to be revived for the digital age." The Observer. 12 September 2012. Web. 23 May 2014.

Boehm-Schnitker, Nadine, and Susanne Gruss. "Introduction: Spectacles and Things - Visual and Material Culture and/in Neo-Victorianism." Neo-Victorian Studies 4.2 (2011): 1-23. Web. 27 May 2014. 
Bowser, Rachel A., and Brian Croxall. "Introduction: Industrial Evolution." NeoVictorian Studies 3.1 (2010): 1-45. Web. 27 May 2014.

Brake, Laurel. "Star Turn? Magazine, Part-Issue, and Book Serialisation." Victorian Periodicals Review 34.3 (2001): 208-227.

Briggs, Asa. Victorian Things. London: Batsford, 1990.

Dahlquist, Gordon. "'Make 'em cry, make 'em laugh, make 'em wait': GW Dahlquist on the nerve-racking challenge of writing a novel in instalments." theguardian. 6 January 2007b. Web. 3 July 2014.

Discovering Dickens: A Community Reading Project. Stanford University. 2005. Web. 14 May 2014.

Domsch, Sebastian. "Monsters against Empire: The Politics and Poetics of NeoVictorian Metafiction in The League of Extraordinary Gentlemen." Neo-Victorian Gothic: Horror, Violence and Degeneration. Ed. Marie-Luise Gutleben and Christian Kohlke. Amsterdam: Rodopi, 2012. 97-121.

Eichhammer, Barbara. "Waren- und Konsumkultur." Viktorianismus: Eine literaturund kulturwissenschaftliche Einführung. Ed. Doris Feldmann and Christian Krug. Berlin: Erich Schmidt Verlag, 2013. 99-111.

Faber, Michel. "Victorian e-values." theguardian. 1 June 2002. Web. 5 May 2014.

Genette, Gérard. Paratexts: Thresholds of Interpretation. 1987. Trans. Jane E. Lewin. Cambridge: Cambridge UP, 1997.

Hantke, Steffen. "Difference Engines and Other Infernal Devices: History According to Steampunk." Extrapolations 40.3 (1999): 244-254.

Hapka, Christopher. Mousehold Words. N.d. Web. 30 April 2014.

Heller, Tamar. Dead Secrets: Wilkie Collins and the Female Gothic. New Haven, CT: Yale UP, 1992.

Hughes, Linda K., and Michael Lund. The Victorian Serial. Charlottesville: UP of Virginia, 1991.

Lauterbach, Edward S. "Victorian Advertising and Magazine Stripping." Victorian Studies 10.4 (1967): 431-434.

Law, Graham. Serializing Fiction in the Victorian Press. Basingstoke: Palgrave, 2000.

Llewellyn, Mark. "What Is Neo-Victorian Studies?" Neo-Victorian Studies 1.1 (2008): 164-185. Web. 27 May 2014.

Murray, Janet H. Hamlet on the Holodeck: The Future of Narrative in Cyberspace. New York: Free Press, 1997. 
Nevins, Jess, et al. "Notes on League of Extraordinary Gentlemen Hardcover Edition." Annotations for Alan Moore Comic Books. Ed. Peter Karpas. 2000. Web. 27 May 2014.

"No Name Reading Project." Dickens Journals Online. Ed. John Drew and Michael Slater. U of Buckingham, 2006. Web. 30 April 2014.

Price Paul, Donna. "Matchworkers." Victorian Britain: An Encyclopedia. Ed. Sally Mitchell. New York: Garland, 1988. 483-484.

Ramamurthy, Anandi. Imperial Persuaders: Images of Africa and Asia in British Advertising. Manchester: Manchester UP, 2003.

Rickett, Joel. “The Bookseller.” theguardian. 9 September 2006. Web. 27 May 2014.

Rutherford, Lara. "Victorian Genres at Play: Juvenile Fiction and The League of Extraordinary Gentlemen." Neo-Victorian Studies 5.1 (2012): 125-151. Web. 27 May 2014.

Schülting, Sabine. “Pray, Did You Ever Hear of Pears' Soap?': Soap, Dirt, and the Commodity in Victorian England." Journal for the Study of British Cultures 8.2 (2001): 137-157.

Sulmicki, Maciej. "The Author as the Antiquarian: Selling Victorian Culture to Readers of Neo-Victorian Novels and Steampunk Comics." Otherness: Essays and Studies 2.1 (2011): n.pag. Web. 29 May 2014.

Thornton, Sara. "The Haunted House of Victorian Advertising: Hysteria, Paranoia, Perversion." Anglophonia/Caliban 15 (2004): 59-74.

Turner, Mark. “Telling of my weekly doings': The Material Culture of the Victorian Novel." Concise Companion to the Victorian Novel. Ed. Francis O’Gorman. Malden, MA: Blackwell, 2005. 113-133.

Wicke, Jennifer. Advertising Fictions: Literature, Advertisement, and Social Reading. New York: Columbia UP, 1988.

Williams, Andy. "Advertising and Fiction in The Pickwick Papers." Victorian Literature and Culture 38.2 (2010): 319-335. 